確かめたいと考えている。

\section{8. あとがき}

塗料による鉄塔および鉄構の防食試験塗装について, 試験条件，塗膜の状況ならびに 1 力年経過した現在まで の過程を中間的に取りまとめてみたが，現在までの結果 では各試料間ならびに下地処理別にみた塗膜変化の状況 および鉄塔と試験板との関連などについて，まだ短期間 の経過をみたに過ぎず，詳細な考察を加えるまでに至っ ていない。したがって今後の結果をまち詳細な検討を加 えていきたいと思っている。なお本塗装試験は 5 力年間 の予定であり, 今後も 1 カ年ごとに塗膜の状態を調査し ていく予定である。
終りに本試験塗装開始に当り種々ご検討を賜った学振 第 97 腐蝕防止委員会鉄塔分科会関係者ならびに全面的 にご協力を頂いた石川島播磨重工(株)技術研究所材料部 長尾間一彦氏, 菅野照造氏, 土田豊二氏および試料の提 供を賜った各塗料会社に対して厚くお礼申し上げます。

なお, 本試験に当り種々ご指導ご協力下された当研究 所 $600 \mathrm{kV}$ 研究班総括担当上之園親佐博士ならびに関係 各位に対し感謝の意を表します。

（昭和 37 年 12 月 5 日受理）

\section{文}

1) 久松敬弘：防蝕技術, 9, No. 10, 27 29 (1960)

2）青木, 島田：防蝕技術, 10, No. 6, 1 4 (1961)

\title{
キャビテーション・エロージョンに対する腐食抑制剤の効果*
}

\author{
栄幸 雄** 鬼 村 吉 郎**
}

\section{Effects of Corrosion Inhibitors on Cavitation-Erosion}

\section{Yukio Sakae and Kichiro Onimura}

Severe cavitation-erosion has often been experienced at the cooling water side of some diesel engine cylinder liners.

To protect against the erosion various protective methods have been tried.

In this paper, the accelerated cavitation-erosion tests were made under the addition of various corrosion inhibitors such as emulsified oils, chromates, nitrites, and organic amine-inhibitor into rfesh water, and also the potential of test pieces

\section{1. 緒言}

中型ディーゼルエンジンのシリンダライナ冷却水側に は激しいピッティングコロージョンが発生することは良 く知られている通りで，その原因はキャビテーションに 起因することがほぼ明らかになっている1,2)。防止対策に ついてもシリンダライナの振動の減少, 空気混入の防 止，水圧上昇等設計上の改良のほか，ニッケルの厚メッ キ $(0.3 \mathrm{~mm} \text { 以上 })^{3)}$, 防食叙装（エポキシ樹脂塗料等） あるいは冷却水処理, 防食覀鉛板4) 取りつけなど種々の 方法が実施されており，その効果の確認されているもの もある。

一般にシリンダライナ冷却水側の腐食防止のための腐

* 昭和 37 年 10 月 15 日 腐食防食討論会(福岡)にて発素

** 新三菱重工(株) 神戸造船所研究部（神戸市兵庫区和田崎町 3) was measured under cavitation conditions.

Inhibited water could reduce the erosion loss by half to quarter when compared with noninhibited one.

From the results of potential measurement during the cavitation test periods, the inhibitive effect of these inhibitors on cavitation-erosion was considered to be due to the formation of adsorbed films which increased the original cavitation-erosion resistance.

食抑制剂としてこれまでクロム酸塩，有機アミン，亜硝 酸塩等が使用され，さらに最近では乳化油が使用される 傾向になってきた。これら各種の防食剤は単なるシリン ダライナの腐食防止という点では多くの使用実例等から も防食効果泩䧳されている。しかしながらキャビテ一 ション・エロージョンに対して防食㓝がどのような挙動 を示すものか济あまりよく知られていないように思われ る。この点に関しては岡本ら5), 露木6), Leith7), Rheingans ${ }^{8)}$ の報告が散見するのみであまりまとまった研究 は見当らない。

そこで本報では乳化油, クロム酸塩, 覀硝酸塩, 有機 アミン等を水道水中に添加した場合のキャビテーション ・エロージョンに対する腐食抑制剤の抑制効果を碰正振 動法で試験するとともに，キャビテーション・エロージ 
ョン発生下において試験片表面の自然電極電位の測定を 行ない, 抑制機構についても若干の検討を試みたもので ある。

\section{2. 試 験 方 法}

$2 \cdot 1$ キャビテーション・エロージョンテスト

試験に使用した装置は碰正振動式キャビテーション試 験装置9)であるがその要目は下記の通りである。

$\mathrm{Ni}$ 振 動子.......外径 $16 \mathrm{~mm}$, 内径 $14.4 \mathrm{~mm}$ 長さ $302 \mathrm{~mm}$

発振器出力... $.5000 \mathrm{~W}$

共振周波数 $\cdots \cdots 6,500 \pm 50 \mathrm{c} / \mathrm{s}$

振 幅……6/100 mm

試験時間は合計 2 時間とし，その間 10 分，20 分，30 分, 60 分, 90 分, 120 分後の重量変化を測定した。試験 温度は試験液槽に試験液を入れ，液温調節器を通し図 1 の循環ポンプ（ストロークポンプ）で液を循環した。こ の場合循環系はすべて塩化ビニルとガラスよりなり采内 の総液量は $5 l$ であり，また試験槽には $750 \mathrm{~m} l$ のオ一 バフロー式ガラス容器を用いた。

試験片は径 $55 \mathrm{~mm}$, 長さ $300 \mathrm{~mm}$ に鋳造した $\mathrm{FC}$ 20 材より図 2 に示した寸法の試験片を機械加工し試験 面はエメリペーパ\#400まで研摩し，ベンゼン，エーテ ル, アルコールで脱脂洗浄, デシケータ中で乾燥の上科 量し試験に供した。

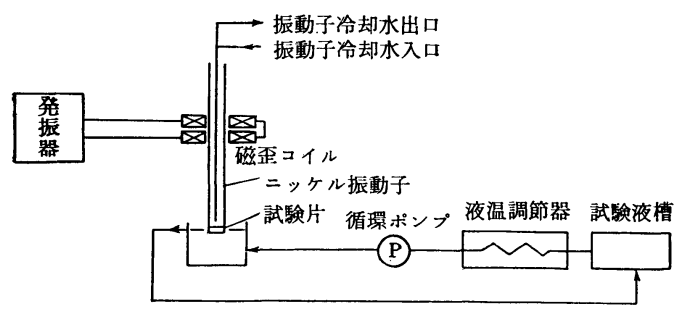

図 1 試験装置略図

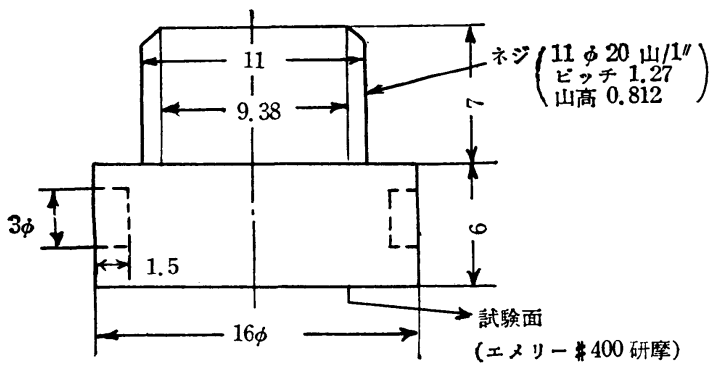

図 2 試験片

試験に供した腐食抑制剤は乳化油（いずれも市販品で 釈化油A 釈化油 $\mathrm{B}$ 㳔油を基油としそれぞれこれに乳化剂，防食 郕等を添加したものである), 有機アミン系抑制剂(市販 品）および化学用一級の重クロム酸カリウムと亜硝酸ソ
一ダの 5 種類で，これを水道水中に溶解させ表 1 に示し たような縕合せで $0.01 〜 1 \%$ の試験液を調整した。調 整した試験液の比重, 粘度, $\mathrm{pH}$ および表面張力の測定 值は表 1 のようであるが，重クロム酸カリウム液の $\mathrm{pH}$ はカセイソーダを添加し 8.5 になるように調整したもの である。

表 1 試験液の諸性質

\begin{tabular}{|c|c|c|c|c|c|}
\hline 試 料 名 & 濃 度 & $\begin{array}{l}\text { 比 重 } \\
15^{\circ} \mathrm{C}\end{array}$ & $\begin{array}{l}\text { 粘. 度 } \\
\mathrm{C} . \mathrm{P} \\
25^{\circ} \mathrm{C}\end{array}$ & $\begin{array}{r}\mathrm{pH} \\
15^{\circ} \mathrm{C}\end{array}$ & $\begin{array}{c}\text { 表面張力 } \\
\text { dyne } \\
21^{\circ} \mathrm{C} C\end{array}$ \\
\hline 乳化 油 $\mathrm{A}$ & $\begin{array}{l}0.5 \% \\
1.0 \%\end{array}$ & $\begin{array}{l}0.9985 \\
0.9995\end{array}$ & $\begin{array}{l}0.961 \\
1.050\end{array}$ & $\begin{array}{l}9.10 \\
9.35\end{array}$ & $\begin{array}{l}37.5 \\
37.9\end{array}$ \\
\hline 乳 化 油 $B$ & $\begin{array}{l}0.5 \% \\
1.0 \%\end{array}$ & $\begin{array}{l}0.9985 \\
0.9992\end{array}$ & $\begin{array}{l}1.005 \\
1.097\end{array}$ & $\begin{array}{l}9.05 \\
9.40\end{array}$ & $\begin{array}{l}37.5 \\
39.7\end{array}$ \\
\hline 有機 フミン系 & $\begin{array}{l}0.1 \% \\
0.01 \%\end{array}$ & $\begin{array}{l}0.9996 \\
0.9995\end{array}$ & $\begin{array}{l}1.705 \\
1.102\end{array}$ & $\begin{array}{l}9.10 \\
7.36\end{array}$ & $\begin{array}{l}32.2 \\
36.8\end{array}$ \\
\hline 重クロム酸カリ & $\begin{array}{l}0.1 \% \\
0.5 \%\end{array}$ & $\begin{array}{l}1.0003 \\
1.0041\end{array}$ & $\begin{array}{l}0.990 \\
1.080\end{array}$ & $\begin{array}{l}8.50 \\
8.50\end{array}$ & $\begin{array}{l}64.2 \\
67.0\end{array}$ \\
\hline 亜硝酸ソーダ & $0.1 \%$ & $\begin{array}{l}1.0001 \\
1.0027\end{array}$ & $\begin{array}{l}1.050 \\
1.065\end{array}$ & $\begin{array}{l}7.30 \\
7.15\end{array}$ & $\begin{array}{l}42.7 \\
51.4\end{array}$ \\
\hline 水 道 水 & $\longrightarrow$ & 0.9991 & 0.894 & 6.60 & 72.59 \\
\hline
\end{tabular}

\section{$2 \cdot 2$ 静置腐食試験}

神戸，高知および高松より取り寄せた各地の都市上水

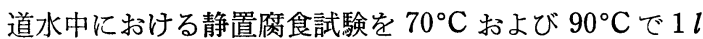
環流冷却器付フラスコ中で行なった。防食剤として添加 したものは乳化油AおよびBを 1～5\% と重クロム酸ソ ーダ $0.2 \%$ であり，試験片は丸棒に鋳込んだ鋳鉄より 径 $30 \mathrm{~mm}$, 厚さ $3 \mathrm{~mm}$ に切削し表面はサンドペーパ \#180で研摩後試験に供した。試験時間は昼間のみ 70 ${ }^{\circ} \mathrm{C}, 90^{\circ} \mathrm{C}$ に加温浸漬し 50 時間（常温浸漬時間 116 時 間)，100 時間 (230 時間)，150 時間（317 時間）浸漬後 の重量变化を測定し，全浸漬時間を基準として腐食速度 を計算した。神戸，高知および高松の上水道水化学分析 值を表 2 に示した。

表 2 各地水道水の化学成分

\begin{tabular}{|c|c|c|c|c|c|}
\hline 項 & 目 & 原水の地域別 & 神 戸 & 高 松 & 高 知 \\
\hline 状 & & 熊 & 無色透明 & 無色透明 & 無色透明 \\
\hline $\mathrm{pH}$ & & & 6.6 & 7.4 & 7.3 \\
\hline 溶 解 & 固 形 分 & $\mathrm{ppm}$ & 91.7 & 203 & 81 \\
\hline 硫 酸 & $1 オ ン$ & $\mathrm{SO}_{4}^{2-} \quad \mathrm{ppm}$ & 21.1 & 16.4 & 3.4 \\
\hline 塩 素 & $1 オ 2$ & $\mathrm{Cl}-\quad$ ppm & 10.8 & 20.7 & 6.0 \\
\hline シ & リ 力 & $\mathrm{SiO}_{2} \quad$ ppm & 4.9 & 40.2 & 7.8 \\
\hline$M>ル$ & カリリ度 & $\mathrm{CaCO}_{3} \mathrm{ppm}$ & - & 78.3 & 40.4 \\
\hline 総 & 硬度 & $\mathrm{CaCO}_{3} \mathrm{ppm}$ & 33.4 & 63.2 & 35.8 \\
\hline カルシ & ウム硬度 & $\mathrm{CaCO}_{3} \mathrm{ppm}$ & 23.4 & 44.2 & 25.3 \\
\hline マグネ & シウム硬度 & $\mathrm{CaCO}_{3} \mathrm{ppm}$ & 9.9 & 19.0 & 10.5 \\
\hline 比 & 抵抗 & $\Omega-\mathrm{cm} \quad 18^{\circ} \mathrm{C}$ & $5.5 \times 10^{3}$ & $5.1 \times 10^{3}$ & $14.9 \times 10^{3}$ \\
\hline
\end{tabular}

\section{$2 \cdot 3$ 自然電極電位の測定}

キャビテーション・エロージョン発生下の試験片表面 
の自然電極電位を測定し, キャビテーション・エロージョ ンの機構ならびに腐食抑制剤の作用機構を検討するため 次のような方法で自然電極電位の測定を行なった。自然 電極電位の測定方法には種々の方法が考えられ著者らも 先に Luggin capillary 法10)で自然電極電位の測定を行 なったが，碰歪振動法の場合被測定電極面の中心部と周 辺部ではキャビテーション強度が異なるので, Luggin tip で間接的に測定するよりもキャビテーション・エロ ージョン発生部の自然電極電位を直接ブリッジを通して 測定する方が良いと思われたので図 3 に示したような試 験片を作製した。すなわちキャビテーション発生面より 径 $0.5 \mathrm{~mm}$ の穴を深さ $3 \mathrm{~mm}$ あけて更にスパナホール

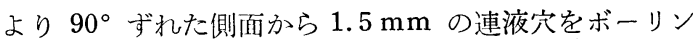
グし，この穴にゴム管を挿入し図4(a)のようにエポキシ 樹脂系接着剤でガラス管と接着しブリッジとした。図 4 (b)はキャビテーション・エロージョン発生下の自然電㥛 電位測定回路である。

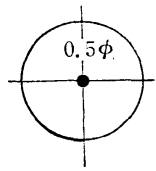

(a)

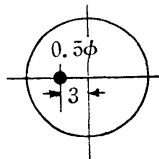

(b)

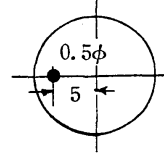

( כ)
図 3 試験片電位測定位置

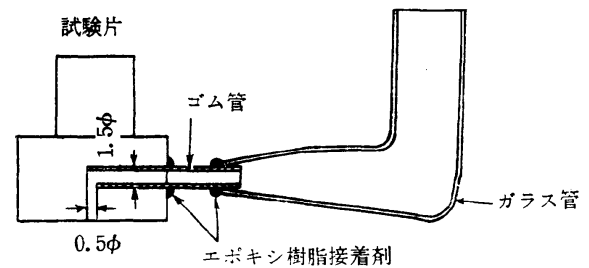

(a) 電位测定試䂆片

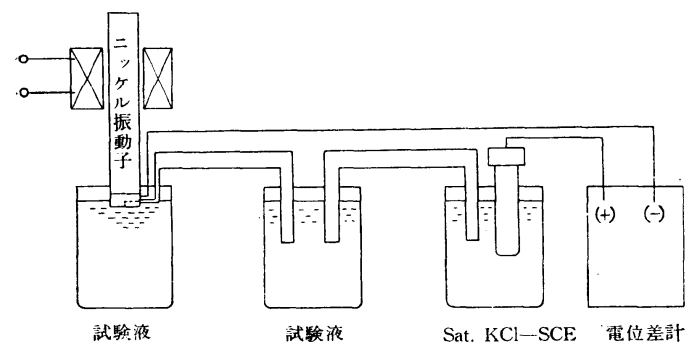

(b) 電位測定回路

図 4 電位測定方法

\section{3. 試験結果ならびに考察}

\section{$3 \cdot 1$ 腐食抑制剤添加液中における侵食量}

水道水中およびこれに各種の腐食抑制剂を添加した液 中における侵食量と時間の関係は図 5 の通りで，腐食抑 制剂を添加したものは無添加の水道水よりも侵食量は少 なく，水道水単独の場合は試験時間が 60 分経過する頃
より侵食量は急増するのに反し腐食抑制剤添加液中では 120 分経過後でもなお侵食量は少なく, 防食率として計 算すれば有機つミン系抑制剤 $(0.1 \%)$ が最も良く $70 \%$ 前後を示し, 次いで乳化油 $\mathrm{A}$, 乳化油 $\mathrm{B}$, 重ク口ム酸 カリウム，业硝酸ソーダの順であったが，いずれも侵食 量を 1/2〜1/4 に減少させうることが涊められた。

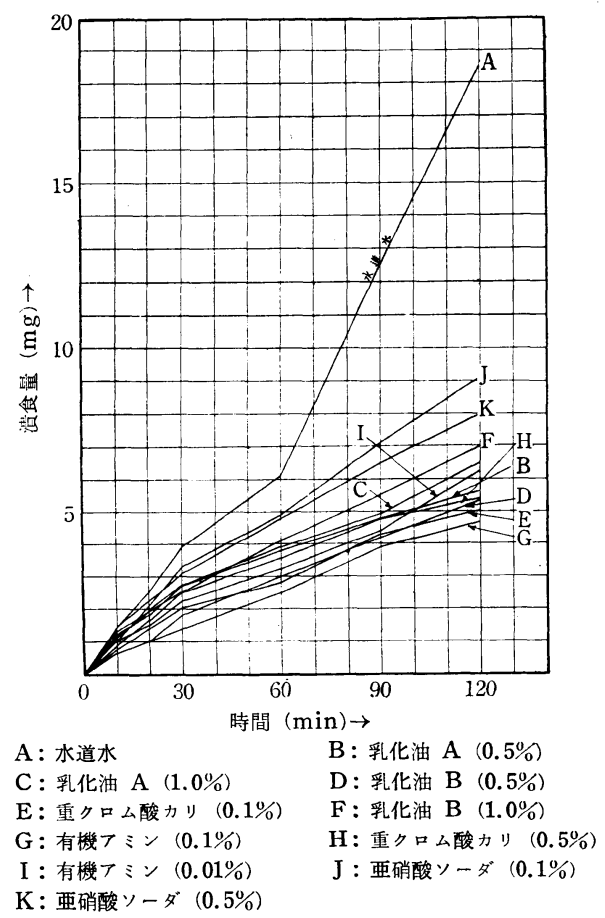

図 5 潰食量と時間の関係

キャビテーション・エロージョンと液質の関係につい ては，試験時の大気圧が一定なら侵食量は試験液の蒸気 圧，粘度等にほぼ反比例し ${ }^{8,9)}$ 表面張力に比例する8)。こ れらの液質が一定の場合は(a)材質の硬度大, (b)抗張力そ の他の機械的強度大, (c)疲労限度大, (d)細密結晶組織で あることなどが耐キャビテーション・エロージョン性の 一応の判定基準として与えられる。今回の場合多少侵食 量にバラッキはあるが液質との問には上に述べたような 関係が見出される。すなわち最も防食率の良かった有機 アミン系では表面張打水道水の $1 / 2$ 以下，乳化油でも これに近い值を示しており，またその他の腐食抑制剤を 添加した液も水道水よりも低い表面張力となっている。 粘度の方から見ても有機アミン系が他の液よりも格別に 高く, キャビテーション強度が試験液の物理化学的因子 にも支配されている証拠で, キャビテーションの発生機 構とともにあわせ検討せね柿ならない。この点について は先に高速度カメラによる観測結果11)の一部を報告した が，その後の研究とあわせ取りまとめ別報に報告する予 
定である。

\section{$3 \cdot 2$ 静置腐食試験結果}

図 6 に試験結果を腐食速度として示した。水道水単独

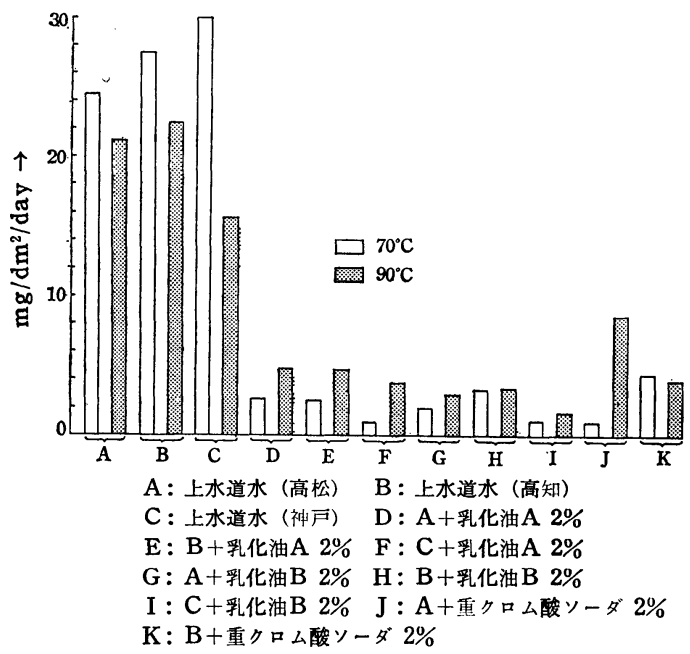

図 6 防食尛添加液中での鋳鉄の腐食速度 $\left(70^{\circ} \mathrm{C}\right.$ および $\left.90^{\circ} \mathrm{C}, 150 \mathrm{hr}\right)$

の場合鋳鉄の腐食速度が $90^{\circ} \mathrm{C}$ よりも $70^{\circ} \mathrm{C}$ の方が多 いのは, 溶存酸素量が $70^{\circ} \mathrm{C}$ の方が多いことに基ゔくた めと考えられ，逆に腐食抑制剤を添加したときは $90^{\circ} \mathrm{C}$ の方が腐食速度が大となるのは腐食抑制郕の能力が低下 することによるものと思われる。ここで露木の現車試験 の結果が報告されているので，これを筆者らの碰正法に よる侵食速度その他と比較すると表 3 のようになる。

露木は MAN 型機関と Sulzer 型機関で試験した結 果, 機関構造の相違によりキャビテーションの発生強度 も異なり，腐食抑制剂の添加によって MAN 型では 1/4〜1/20, Sulzer 型ではほとんど完全に点食を防止で きるとしている。また Speller らはシ リンダライナのキャビテーション・エ ロージョンによる損傷速度を推定して いるが，これによれば重量減少で 16,000 mdd になっている。これらの ことより磁正振動法による 2 時間の試 験が実際のシリンダライナに生ずるキ ヤビテーション・エロージョンによる 損傷速度と比較的一致し, かつ静置腐 食のほぼ数干倍の加速度を持つ試験方 法であることがうかがえる。

$3 \cdot 3$ キャビテーション・エロージョ 発生時の自然電極電位

図 7 (a)は通常の方法により測定して 得られた静置液中の飽和甘承電極に対

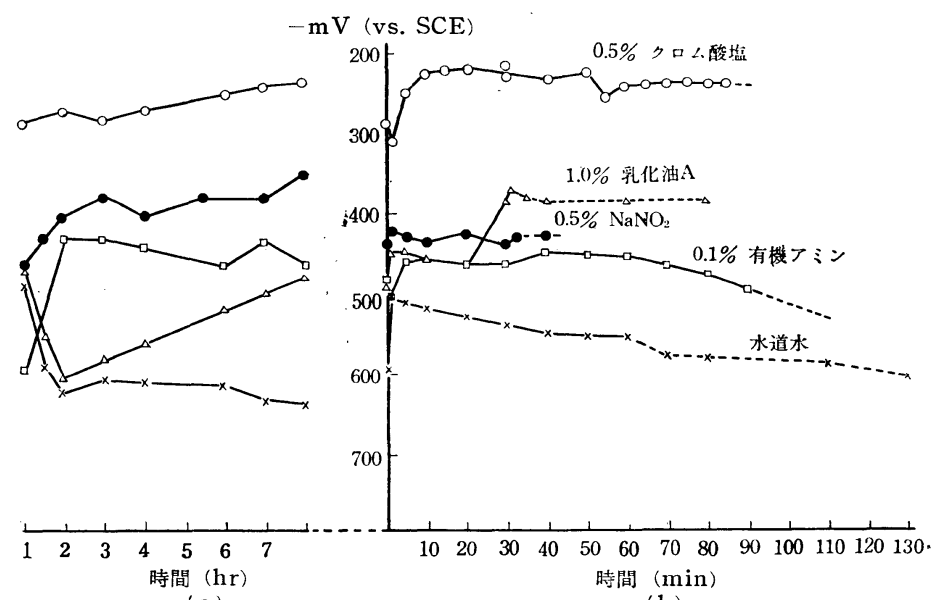

(a)

(b)

図 7 (a) 静止時の自然電極電位 (b) キャビテーション下の自然電極電位

\begin{tabular}{|c|c|c|c|}
\hline & $\begin{array}{l}\text { 磁 票 } \\
\left(25^{\circ} \mathrm{C}\right)\end{array}$ & $\begin{array}{c}\text { 静真應食 } \\
\end{array}$ & $\begin{array}{l}\text { 現車武驗) } \\
\text { (スルザー型) }\end{array}$ \\
\hline 水道水中 & 11,100 & $25 \sim 30$ & - \\
\hline 抑制剂添加液 & $3,000 \sim 5,000$ & $1 \sim 4$ & $0.1 \sim 1$ \\
\hline
\end{tabular}

する鋳鉄試験片の経時変化を示したもので，約 1 時間経 過後乳化油 $\mathrm{A}$ 以外注定電位を示している。

図 7 (b)は先の試験で約 1 時間後に自然電極電位は安定 することがわかったので，図 $3(\mathrm{a})$ に示した試験片を振動， 子に固定し各試験液中に $30 \sim 60$ 分浸漬放置後, 規定の 条件で装置を運転しキャビテーション・エロージョン発 生時の自然電極電位を測定したものである。

この結果によると水道水単独の場合には，キャビテー ション発生直後試験片の電位は約 $100 \mathrm{mV}$ 貴となり,後 次第に電位は降下し 60 分後には試験直後よりも $50 \mathrm{mV}$ 㫣になっている。試験を 60 分で打切り以後電位測定の. みを行なったものが点線で記したもので 130 分後には試 験前の自然電極電位まで戻っている（他の試験液の場合 も同じように点線で記されているのはキャビテーション テスト終了直後よりの自然電極電位の経時変化である)。

有機アミン，クロム酸塩添加液中ではキャビテーショ ン発生直後, 電位はいったん約 $20 \sim 30 \mathrm{mV}$ 卑となり, 次いで直ちに貴の方向に変化するが試験時間が経過する に従い電位は早へ移行する。乳化油と亜硝酸塩は試験直 後水道水と同じような傾向をたどるが，特に乳化油では 30 分後急激な電位上昇が認められている。

図 8 注電位測定仙置と自然電極電位の経時变化を示し たものである。参考のため海水中でのデータも付したが 中心部ほど電位の変化量が大きく，この点はクロム酸塩 の場合も同じで中心部と周辺部ではキャビテーション強 度が異なることによるものであろう。

以上述べたような自然電極電位の変化については次の. 


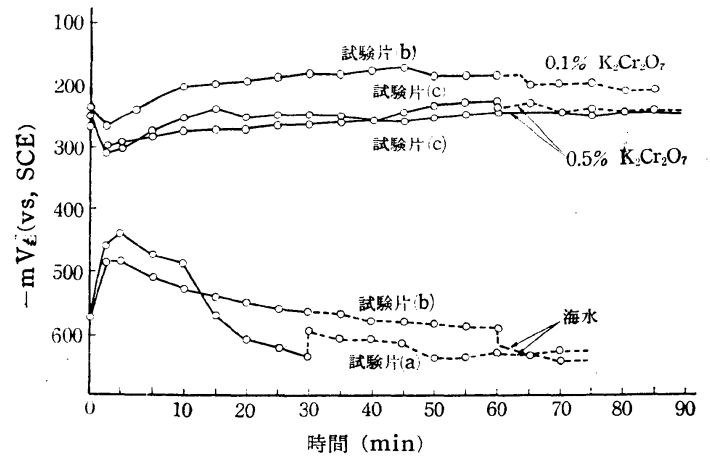

図 8 電位測定位置の影響と自然電極電位の経時变化

ように考察される。まず水道水単独でキャビテーション 発生直後電位が急上昇するの液中の溶存酸素の吸着等 により試験片表面が急激に分極されるためであり，この 状態は時間の経過とともに復極される。抑制用添加液で は復極速度はやや遅くなり，海水のような腐食性の大き い液では水道水中よりも復極速度が大きく，また試験片 の中心部と周辺部でも相違がある。

有機アミン，クロム酸塩の場合は，キャビテーション テストに入る前にすでに表面に腐食抑制剤が吸着されて いるが，キャビテーション発生と同時にこの吸着膜の一 部が破壊され活性面を露出する。この結果自然電位は一 時帛となるが，ただちにキャビテーション作用により活 性面への吸着被膜の補修が行なわれ局部陽極部の分極が 増大し電位の上昇をきたす。これが再び時間の経過とと もに復極され腐食電位は降下線をたどる。

乳化油, 悪硝酸塩ではキャビテーション発生と同時に 電位の上昇が認められるのは水道水単独の場合と同じよ うに液中の溶存酸素による分極作用が現われたものと考 えられるが，復極の速度は腐食抑制剤を含むため水道水 単独の場合よりも遅くなっている。

以上行なった各種の試験とその結果よりキャビテーシ ョン・エロージョンの機構について若干付言してみた い。まず侵食量と時間の関係について坧食抑制剂の添 加と無添加の場合では侵食の速度が異なり一般的傾向は 図9のようになるものと考えられる。

図 9 において $\theta_{1}, \theta_{2}$ 注試験材料と環境によって定ま るキャビテーション・エロージョンに対する初期抵抗と でも呼ばれる侵食速度であり，当然のことながら両者の 差が大きいほど腐食抑制剤は効果的である。初期抵抗の 範囲内では侵食量は液の化学的性質, 材料の耐食性が大 きな因子となり，これに左右される。

$t_{1}, t_{2}$ までの時間が初期抵抗として扱われる範囲で, 具体的には磁歪振動法の場合にはキャビテーション強度 とくにニッケル管の振幅量によってその時間は決定され る。キャビテーション・エロージョンに対し電気防食や

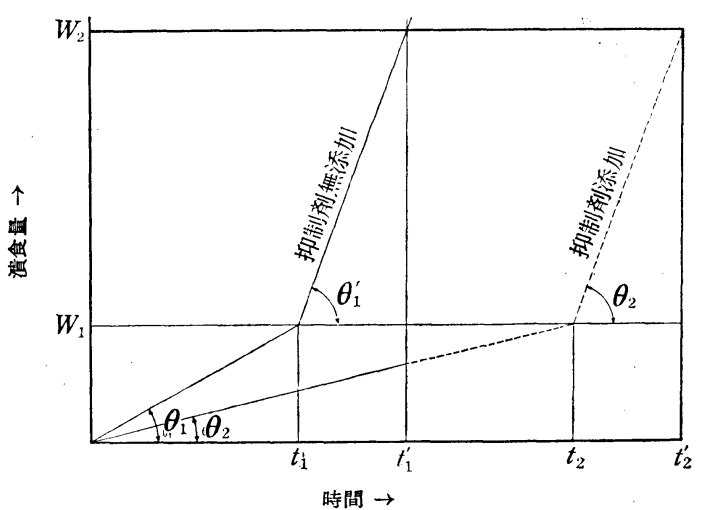

図 9 潰食量と時間の関係（模型）

腐食抑制凨の效果が認められるのは主としてこの期間内 であり，かつこれらの防食対策は初期抵抗の期間安延長 させることに役立っている。

初期抵抗の期間を経過するとキャビテーションの支配 領域となり侵食量は急増する。この侵食量は主として物 理的破壊作用によるもので試験容器々底に金属粒子が認 められることや，またガラス，ゴム，合成樹脂等の非金 属材料でも同じように侵食量を示す結果9) から説明でき る。腐食抑制剤添加液中あるいは電気防食を実施した場 合でも，初期抵抗期間経過後のキャビテーション領域で は電位計測結果等から推定して $\theta_{1}^{\prime} と \theta_{2}^{\prime}$ はほぼ近い值 になるものと考えられる。

\section{4. 結 言}

キャビテーション・エロージョンに対する腐食抑制戍 の効果について試験した結果を取りまとめ報告した。キ ヤビテーション・エロージョンの機構そのものについて も解明されていない点が多々あるが，筆者らは材料の耐 食性と試験液の物理化学的性質に左右される初期抵抗の 段階と物理的破壊により侵食を受ける二つの過程でキャ ビテーション・エロージョンの機構を推論し, 腐食抑制 剂の作用効果は吸着膜の生成による初期抵抗の増大によ るものと考えた。なお本研究の絬果を実動のディーゼル エンジン・シリンダライナの防食に適用し成果をあげて いることを付記する。 （昭和 38 年 1 月 5 日受理）

\section{参考文 献}

1) F. N. Speller: Corrosion Causes and Prevention, p. 237, McGraw-Hill (1951)

2) F. N. Speller: Corrosion, 6, No. 7, 209 (1950)

3) 原田, 西川：金属表面技術, 9, No. 1, 6 (1958)

4) 瀬尾：腐食防食討論会 (講演) 昭 $37-10$ 月

5) 岡本ほか：日本金属学会（講演）昭 30-4 月

6）督木：防蝕技術, 10, No. 11, 481 (1961)

7) W.C. Leith: J. Basic Eng., Dec. $795(1960)$

8) W. J. Rheingans: Trans. ASME, July 705 (1950)

9) 栄: 防触技術, 6, No. 1, 1 (1957)

10) 栄, ほか: 未発表

11) 栄: 腐食防食討論会（講演）炤 34-10月 